\title{
Is the Sevier Desert reflection of west-central Utah a normal fault?: Comment and Reply
}

\section{COMMENT}

\author{
Richard W. Allmendinger \\ Department of Geological Sciences, Cornell University, Ithaca, \\ New York 14853-1504 \\ Frank Royse, Jr. \\ 6984 Urban Street, Arvada, Colorado 80004
}

The continuing discussion of the Sevier Desert region, almost 20 years after MacDonald's (1976) classic paper, provides a measure of the significance of the region as well as the non-uniqueness of seismic reflection data interpretation. The article by Anders and Christie-Blick (1994) and the nearly simultaneous publication of similar ideas by Hamilton (1994) raise important questions. The interpretation of a Sevier Desert detachment has always been a hypothesis to be tested rather than a fact. In our opinion, however, Anders and Christie-Blick and Hamilton have ignored a variety of basic geologic data requiring the presence of a major low-angle normal fault on the east side of the Sevier Desert basin.

Anders and Christie-Blick (1994) suggested that the Sevier Desert basin is not bounded by significant Cenozoic normal faults. However, they provided no plausible scenario to explain the accumulation of 3.5-4.0 km of Oligocene to Holocene strata in the basin or the geometry of the basement surface. Basement beneath the basin depocenter is as much as $4.5 \mathrm{~km}$ higher than basement farther east (see Plate 1 of Allmendinger, 1992). The age of this arch must be Oligocene or younger because east-dipping Eocene beds on the east flank of the Pavant Range parallel the seismically defined, eastdipping Precambrian basement surface. Further support for Tertiary basement uplift comes from fission-track studies of cuttings from boreholes in the Sevier Desert. The apatite fission-track age of Prospect Mountain Quartzite from 6000 to $6500 \mathrm{ft}$ (about 1818-1970 m) in the Cominco well is $8.5 \pm 2.2 \mathrm{Ma}$. Zircon fission-track ages from $1635 \mathrm{Ma}(\mathrm{K}-\mathrm{Ar}$ and Rb-Sr) granitic gneiss from the interval 13,610$15,537 \mathrm{ft}$ (about 4124-4708 m) in the Arco Meadow Federal well are between $10.8 \pm 0.9$ and $13.0 \pm 1.0 \mathrm{Ma}$. Anders and ChristieBlick (1994) would have subsidence in the Sevier Desert Basin occur simultaneously with uplift of the underlying basement surface, while somehow forming and maintaining a planar "unconformity" between Paleozoic and Tertiary. We suggest that basin subsidence and basement uplift are linked; footwall uplift during normal faulting (e.g., Spencer, 1984, and subsequent work) provides the simplest explanation.

The crux of the Anders and Christie-Blick (1994) interpretation concerns the use of microfractures in well cuttings to evaluate zones of deformation. Cuttings are notoriously difficult to pinpoint in depth, let alone tie to seismic time sections. Furthermore, Anders and Christie-Blick compared their observations only to sparse data on thrust faults and high-angle normal faults rather than the myriad of well-exposed, low-angle normal faults around the core complexes, particularly those where growth strata overlie carbonate rocks. Also, the role of plastic deformation of salt along the detachment does not seem to have been evaluated.

Anders and Christie-Blick (1994) assumed that the Sevier Desert detachment is located precisely at the contact between Tertiary and Paleozoic. However, exposed detachments are commonly composite structures in which different segments have different dis- placement histories (e.g., Lister and Davis, 1989). The exact location of the samples analyzed with respect to the surface(s) of major movement is very difficult to ascertain.

The position of the Canyon and Pavant thrusts beneath and west of the Sevier Desert is a key question for section balancing. Most workers assume that the House and Cricket Range strata are in the upper plate of these thrust faults. The present eastward dip of the exposed Pavant thrust parallels the basement surface and thus was acquired after the Eocene. The exposure of the trailing edges of the thrusts in the ranges east of the Sevier Desert basin require normal fault offset or the selective erosion of a very unusual thrust geometry, which is unsupported by surface, seismic, or well data.

A fault contact would also seem to be required by the eastwarddipping Oligocene and pre-Tertiary rocks on the west side of the Sevier Desert. The core of this dip panel, clearly imaged by both COCORP and some industry data, is Paleozoic and Precambrian rocks, not salt. We are unconvinced by Anders and Christie-Blick's interpretation that the reflection seen on COCORP and industry data is the result of a fortuitous alignment. The estimated 30 to 40 $\mathrm{km}$ of displacement was based on the assumption that the hangingwall cutoff of the Canyon Range thrust is in this dip panel. Displacement, however, should decrease up dip to the east. The existing cross sections of the Sevier Desert area are not perfect, but the regional geology constraining the nature of the Sevier Desert detachment were ignored in Anders and Christie-Blick (1994).

Underlying this debate is the continuing suspicion that lowangle normal faults are mechanically impossible. Although the Sevier Desert detachment is a serious challenge to "rolling hinge" models, it is only one of many detachment systems in which both hanging-wall and footwall strata nearly parallel the low-angle detachment surface across large distances.

The otherwise thought-provoking paper by Anders and Christie-Blick (1994) contains inaccurate and selective referencing of previous work. Allmendinger et al. (1983) explicitly stated that they could not tell whether the Sevier Desert detachment was, or was not, a reactivated thrust. The only published cross sections of the Sevier Desert by the Cornell group (Allmendinger, 1992; Allmendinger et al., 1986) either showed both possibilities or interpreted the Sevier Desert detachment as, in large part, a reactivation of the Pavant Range thrust; neither paper was cited. Anders and ChristieBlick's unreferenced interpretation of "a ramp anticline associated with Sevier-aged thrusting" was also made by Allmendinger et al. (1983, and subsequent papers) and much earlier still by others on the basis of surface geology alone.

\footnotetext{
ACKNOWLEDGMENT

We thank Chevron Production Company for permission to publish the geochronology cited here.

\section{REFERENCES CITED}

Allmendinger, R. W., 1992, Thrust and fold tectonics of the western United States exclusive of the accreted terranes, in Burchfiel, B. C., et al., eds., The Cordilleran orogen: Conterminous U.S.: Boulder, Colorado, Geological Society of America, Geology of North America, v. G-3, p. 583-607.

Allmendinger, R. W., Sharp, J. W., Von Tish, D., Serpa, L., Kaufman, S., Oliver, J., and Smith, R. B., 1983, Cenozoic and Mesozoic structure of the eastern Basin and Range Province, Utah, from COCORP seismic reflection data: Geology, v. 11, p. 532-536.

Allmendinger, R. W., Farmer, H., Hauser, E., Sharp, J., Von Tish, D., Oliver, J., and Kaufman, S., 1986, Phanerozoic tectonics of the Basin and Range-Colorado Plateau transition from COCORP data and geologic data: A review, in Barazangi, M., and Brown, L. D., eds., Reflection seismology: The continental crust: American Geophysical Union Geodynamics Series, v. 14, p. 257-268.
} 
Anders, M. H., and Christie-Blick, N., 1994, Is the Sevier Desert reflection of west-central Utah a normal fault?: Geology, v. 22, p. 771-774.

Hamilton, W. B., 1994, "Sevier Desert Detachment," Utah; a nonexistent structure: Geological Society of America Abstracts with Programs, v. 26, no. 2, p. 57.

Lister, G. S., and Davis, G. A., 1989, The origin of metamorphic core complexes and detachment faults formed during Tertiary continental extension in the northern Colorado River region, U.S.A.: Journal of Structural Geology, v. 11, p. 65-94.

MacDonald, R. E., 1976, Tertiary tectonics and sedimentary rocks along the transition: Basin and Range province to plateau and thrust belt province, Utah, in Hill, J. G., ed., Symposium on geology of the Cordilleran hingeline: Denver, Rocky Mountain Association of Geologists, p. 281-317.

Spencer, J. E., 1984, Role of tectonic denudation in warping and uplift of low-angle normal faults: Geology, v. 12, p. 95-98.

\section{REPLY}

\section{Mark H. Anders, Nicholas Christie-Blick, Stewart Wills Department of Geological Sciences and Lamont-Doherty Earth Observatory of Columbia University, Palisades, New York 10964-8000}

We concur with Allmendinger and Royse's assessment of the detachment interpretation for the Sevier Desert reflection as a "hypothesis to be tested." We reported on an attempt to do just that: to look for evidence for fault-related deformation in samples from two boreholes that intersect this feature. The absence of evidence for cataclasis in the inferred hanging-wall block or ductile deformation in the footwall naturally raises some interesting issues for the tectonic interpretation of the Sevier Desert. In drawing attention to these issues, we have not "ignored" any basic geologic data, nor are we aware of any data that "require" the presence of a major lowangle normal fault.

Location of the Hypothesized Detachment. As Allmendinger and Royse point out, the correlation of seismic and borehole data and the location of geologic contacts in boreholes on the basis of cuttings are each subject to uncertainties. Indeed, we addressed these issues in our paper. Each borehole selected for our study is located directly on a seismic reflection line. Geophysical logs are available. Cuttings were recovered at $3 \mathrm{~m}$ intervals and, in the case of the ARCO Hole-in-the-Rock well, we were able to examine core recovered from within $15 \mathrm{~m}$ of the inferred Paleozoic-Tertiary contact. That contact is among the most prominent in each hole, and it corresponds to a marked change in lithology from clastic sediments above to carbonate rocks below. Our data demonstrate that caving is not a significant source of uncertainty. The proportion of sandstone and siltstone chips (Tertiary) decreases abruptly downhole within one 3 $\mathrm{m}$ sampling interval after the first appearance of carbonate rocks, from $82 \%$ to less than $25 \%$ in the ARCO Hole-in-the-Rock well and from $70 \%$ to less than $17 \%$ in ARCO Meadow Federal \#1.

Could the detachment have cut down into the Paleozoic in the area of the boreholes studied, the Paleozoic-Tertiary contact corresponding to the unconformable top of a rider block? This is possible, but we think unlikely. In the vicinity of each borehole, reflections above and below the inferred detachment are parallel. Any rider blocks would therefore have to be below seismic resolution (thinner than $100 \mathrm{~m}$ ) or relatively tabular, and in that case the chance of encountering a depositional top would be remote. Could the detachment have cut up section into the Tertiary? Again, there is nothing to indicate this in the seismic reflection data, and none of the chips examined from the Tertiary section yielded microfracture indices above background levels.

Character of Brittle Deformation. Allmendinger and Royse suggest that the character of brittle deformation along an upper-crustal low-angle normal fault might differ from that associated with highangle normal faults and thrust faults. We fail to understand why that would be the case. Moreover, we have sampled the Cave Canyon detachment fault zone in the Mineral Mountains-located directly south of the Sevier Desert and interpreted by Coleman and Walker
(1994) to be a splay of the Sevier Desert detachment-and found that at a distance of up to $500 \mathrm{~m}$ from the fault surface, the microfracture index is nearly 500 (all grains extensively fractured).

Evidence of Footwall Uplift. Allmendinger and Royse present some interesting arguments concerning evidence for footwall uplift during extension. They point out that Precambrian crystalline rocks encountered beneath the Sevier Desert basin are as much as $4.5 \mathrm{~km}$ higher than basement farther east (Plate 10 of Allmendinger, 1992; Royse, 1993). Uplift is interpreted as Oligocene or younger on the basis of eastward tilting of Eocene strata on the eastern flank of the Pavant Range and young fission-track closure ages. Have Allmendinger and Royse considered the possibility that the basement beneath the Sevier Desert might be located within a Sevier-age thrust sheet, and that the tilting of the Eocene beds might be due in part to high-angle normal faulting east of the Pavant Range (as suggested by Villien and Kligfield, 1986)?

We are skeptical about the tectonic significance of the fissiontrack data. The $8.5 \mathrm{Ma}$ apatite age in the Cominco well is from the inferred hanging-wall block. How is this date relevant to the detachment hypothesis? The ARCO Meadow Federal \#1 well, which yielded zircon ages of between 11 and $13 \mathrm{Ma}$, is located a mere $4 \mathrm{~km}$ from a Quaternary volcanic center. Perhaps these young ages have more to do with late Cenozoic magmatism than uplift.

Origin of Basin and Requirements for Balanced Cross Sections. Another objection raised by Allmendinger and Royse is that we have not provided a plausible explanation for the origin of the Sevier Desert basin or taken into account all observations needed to balance cross sections. One possibility is that the basin owes its existence in part to high-angle normal faulting. Contrary to the assertion of Allmendinger and Royse, nowhere did we deny the existence of such faults. In fact, high-angle normal faults observed along the western flanks of the Canyon and Pavant ranges may provide a way of tracing the trailing edges of Canyon Range and Pavant thrusts back into the subsurface beneath the House and Cricket Ranges, as appears to be indicated by the stratigraphy.

Allmendinger and Royse argue that a detachment is required to explain a seismically imaged eastward-dipping panel of Oligocene and pre-Tertiary strata along the western side of the basin. The Oligocene timing of tilting is based on isotopic dating of volcanic rocks in the Gulf Oil Gronning \#1 well. However, the tie to seismic data assumed an average seismic velocity of $8000 \mathrm{ft} / \mathrm{s}$ (about 2424 $\mathrm{m} / \mathrm{s})$ for the Tertiary rocks. Higher velocities $(10500 \mathrm{ft} / \mathrm{s} ; 3181 \mathrm{~m} / \mathrm{s})$ recorded in the Tertiary of nearby boreholes suggest that the dipping strata may be entirely of Paleozoic age or older, not Oligocene, and hence not relevant to either the existence of the supposed detachment or its age.

We agree with Allmendinger and Royse concerning the inherent "non-uniqueness" of seismic interpretation. We think that continuous coring through the Sevier Desert reflection is needed. If funding for such a program is forthcoming, we look forward to their input in the selection of drilling sites and the interpretation of the data obtained.

\section{REFERENCES CITED}

Allmendinger, R. W., 1992, Fold and thrust tectonics of the western United States exclusive of the accreted terranes, in Burchfiel, B. C., et al., eds., The Cordilleran orogen: Conterminous U.S.: Boulder, Colorado, Geological Society of America, Geology of North America, v. G-3, p. 583-607.

Coleman, D. S., and Walker, J. D., 1994, Modes of tilting during extensional core complex development: Science, v. 263, p. 215-218.

Royse, F., Jr., 1993, Case of the phantom foredeep: Early Cretaceous in west-central Utah: Geology, v. 21, p. 133-136.

Villien, A., and Kligfield, R. M., 1986, Thrusting and synorogenic sedimentation in central Utah, in Peterson, J. A., ed., Paleotectonics and sedimentation in the Rocky Mountain region, United States: American Association of Petroleum Geologists Memoir 41, p. 281-307. 